\title{
The relation of cognitive learning strategies to psychosocial employability attributes amongst black adult learners in the economic and management sciences field
}

\begin{tabular}{|c|c|}
\hline \multicolumn{2}{|c|}{$\begin{array}{l}\text { Authors: } \\
\text { Melinde Coetzee }^{1} \\
\text { Ingrid L. Potgieter }\end{array}$} \\
\hline \multicolumn{2}{|c|}{$\begin{array}{l}{ }^{1} \text { Department of Industrial } \\
\text { and Organisational } \\
\text { Psychology, University of } \\
\text { South Africa, South Africa }\end{array}$} \\
\hline \multicolumn{2}{|c|}{$\begin{array}{l}{ }^{2} \text { Department of Human } \\
\text { Resource Management, } \\
\text { University of South Africa, } \\
\text { South Africa }\end{array}$} \\
\hline \multicolumn{2}{|c|}{$\begin{array}{l}\text { Correspondence to: } \\
\text { Melinde Coetzee }\end{array}$} \\
\hline \multicolumn{2}{|c|}{$\begin{array}{l}\text { Email: } \\
\text { coetzm1@unisa.ac.za }\end{array}$} \\
\hline \multicolumn{2}{|c|}{$\begin{array}{l}\text { Postal address: } \\
\text { PO Box 392, Pretoria 0003, } \\
\text { South Africa }\end{array}$} \\
\hline \multicolumn{2}{|c|}{$\begin{array}{l}\text { Dates: } \\
\text { Received: } 20 \text { May } 2013 \\
\text { Accepted: } 25 \text { Feb. } 2014 \\
\text { Published: } 31 \text { July } 2014\end{array}$} \\
\hline \multicolumn{2}{|c|}{$\begin{array}{l}\text { How to cite this article: } \\
\text { Coetzee, M., \& Potgieter, } \\
\text { I.L. (2014). The relation of } \\
\text { cognitive learning strategies } \\
\text { to psychosocial employability } \\
\text { attributes amongst black } \\
\text { adult learners in the } \\
\text { economic and management } \\
\text { sciences field. SA Journal } \\
\text { of Human Resource } \\
\text { Management/SA Tydskrif vir } \\
\text { Menslikehulpbronbestuur, } \\
\text { 12(1) Art. \#554, } 12 \text { pages. } \\
\text { http://dx.doi.org/10.4102/ } \\
\text { sajhrm.v12i1.554 }\end{array}$} \\
\hline $\begin{array}{l}\text { Copyright: } \\
\text { (C) 2014. The A } \\
\text { Licensee: AOSI } \\
\text { OpenJournals. } \\
\text { is licensed und } \\
\text { Creative Comn } \\
\text { Attribution Lic }\end{array}$ & $\begin{array}{l}\text { uthors. } \\
\text { S } \\
\text { This work } \\
\text { ler the } \\
\text { nons } \\
\text { ense. }\end{array}$ \\
\hline Read online: & $\begin{array}{l}\text { Scan this QR } \\
\text { code with your } \\
\text { smart phone or } \\
\text { mobile device } \\
\text { to read online. }\end{array}$ \\
\hline
\end{tabular}

Orientation: Research provides empirical evidence of the importance employers and employees attach to continuous learning and development opportunities as aspects of employees' employability, retention and job and career satisfaction.

Research purpose: The objective of the research was to investigate the relation between adult learners' cognitive learning strategies (measured by the examination preparation inventory) and their psychosocial employability attributes (measured by the employability attributes scale).

Motivation for the study: Recent research has made important progress in understanding the notions of cognitive learning styles in learning and psychosocial employability attributes in sustaining individuals' employability in the contemporary world of work. However, research on how adult learners' cognitive learning strategies influence the psychosocial attributes they need to manage and sustain their employability has been lacking.

Research approach, design and method: A quantitative cross-sectional survey design was used, involving a stratified proportional random sample of 1102 predominantly early career black female undergraduate level adult learners. The participants were enrolled for distance learning studies in the economic and management sciences field at a South African higher education institution.

Main findings: Canonical correlation and multiple regression analysis indicated the abstract theoretical and factual practical cognitive learning strategies as useful predictors of the participants' overall level of psychosocial employability attributes and especially their levels of career self-management and proactivity.

Practical/managerial implications: Learning practitioners should strive to integrate cognitive learning strategies in the design of learning and assessment activities in order to foster the psychosocial employability attributes adult learners need to manage their continued employability in the contemporary workplace.

Contribution: The study contributes new insights to the employability and learning and education literature. The results may potentially inform formal learning and assessment design in order to improve adult learners' learning performance and employability.

\section{Introduction}

\section{Focus of the study}

Globally, the employability of existing and prospective employees continues to be a matter of major concern for employers (Guzman \& Choi, 2013; Savickas, 2011). Employability is associated with the notion of lifelong learning in a rapidly changing and technologically advancing knowledge economy (Steur, Jansen \& Hofman, 2012; Williams, 2012). Employers and their employees increasingly realise that in order to flourish in a highly competitive and turbulent business environment they need to invest in the continued education, training and development of their employees (Tshilongamulenzhe, 2012). In addition, the South African national skills development legislation emphasises the design of workplace-based training and learning programmes to enhance the employability of employees (Coetzee, 2013a; Tshilongamulenzhe, 2012). Research also provides empirical evidence of the importance employers and employees attach to continuous learning and development opportunities as aspects of the employees' employability, retention, organisational commitment and job and career satisfaction (Joāo \& Coetzee, 2012; Tshilongamulenzhe, 2012; Van Dyk \& Coetzee, 2012). 
Learning practitioners involved in training and development initiatives further realise the importance of understanding how individuals' learning preferences and personality attributes influence their motivation and ability to learn and perform optimally in a learning and assessment environment (Choi \& Jacobs, 2011; Kiguwa \& Silva, 2007). Although research indicates that individuals' learning style preferences drive the actual skills or competencies that they require to optimally and successfully engage in learning and assessment activities (Sugahara \& Boland, 2010), research on how adult learners' cognitive learning strategies influence the psychosocial attributes they need to manage and sustain their employability has been lacking. Understanding the relationship between these variables could potentially bring new insights to the design of formal learning and development programmes and help to further the continued employability of adult learners attending these programmes.

\section{Background to the study}

Recent research has made important progress in understanding the notions of cognitive learning styles and preferences in workplace-based learning (Choi \& Jacobs, 2011; Hosford \& Siders, 2010; Kiguwa \& Silva, 2007) and psychosocial employability attributes in sustaining individuals' employability in the contemporary world of work (Bezuidenhout, 2011; Fugate, Kinicki \& Ashforth, 2004; Pool \& Sewell, 2007; Potgieter, 2012). In the context of the present study, the notion of learning strategies is understood as the cognitive-behavioural strategies individuals prefer to adopt when engaging in formal learning and studying activities (Williams, Rudyk \& Staley, 2004). Learning and studying activities may involve preparing for an examination or any type of formal assessment activity that forms part of the individual's lifelong learning agenda. Adult learners who engage in formal workplace-based training and learning or further their qualifications at a higher education institution are frequently exposed to formal learning and assessment events (Coetzee, 2013a; Tshilongamulenzhe, 2012).

The presence of specific, identifiable learning strategies indicates the likelihood that an individual will engage in certain cognitive behaviours, thereby enabling one to predict the probability of an individual's preferred cognitive learning behaviours and strengths (Williams et al., 2004). Research by Williams et al. (2004) suggests that individuals are energised or affronted by environmental stimuli that either encourage or discourage the adoption of positive learning behaviours. Similarly, some individuals enjoy dealing with abstracttheoretical information whilst others prefer dealing with factual, practical information when engaging in learning activities. Some individuals prefer using an analytical, logical approach to organise learning content whilst others prefer to organise learning content based on what they find as personally meaningful. Individuals may also be highly organised in their approach to learning or prefer to follow a less organised and more open-ended approach to their learning (Williams et al. 2004).
Research on individual differences further provides evidence in support of the link between cognitive coping and approaches to learning and studying. Learning and studying approaches or strategies are viewed as cognitive processes that are grounded in the general coping strategies people adopt to deal with anxiety-creating circumstances (Moneta, Spada \& Rost, 2007). Preparing for formal learning assessments or examinations and dealing with the uncertainties of future career pathways and more frequent career transitions are known to provoke anxiety (Moneta et al., 2007; Savickas \& Porfeli, 2012; Williams et al., 2004). As a consequence, the present study was interested in understanding how the cognitive learning strategies of adult learners relate to the psychosocial attributes that are known to influence their employability in the contemporary workplace (Bezuidenhout, 2011; Fugate et al., 2004; Pool \& Sewell, 2007; Potgieter, 2012).

The notion of psychosocial employability attributes relates to the positive psychological career resources and capacities that individuals need in the proactive management of their career development (Bezuidenhout, 2011; Coetzee, 2013b). In an employment environment characterised by uncertainty, fast-changing technological and knowledge advances, more frequent career transitions and blurred career progression pathways, individuals are seen as active agents that need to take ownership of their careers (Lent, 2013; Savickas, 2011). Employees are therefore required to engage in career and learning behaviours that help them to adapt to changing circumstances and develop the skills they need to sustain their employability (Lent, 2013; Savickas, 2011; Savickas \& Porfeli, 2012). Psychosocial attributes are also seen as the positive psychosocial capital that enhances the individual (psychological) and work (social) interface and that makes individuals valued assets to both prospective and current employers (Avey, Reichard, Luthans \& Mhatre, 2011; Fugate et al., 2004). These attributes include, for example, proactive career self-management behaviours, career resilience and adaptability, and core positive self-evaluations such as selfefficacy, self-esteem, proactivity, locus of control, emotional literacy and sociability (Bezuidenhout, 2011; Fugate et al., 2004).

\section{Research purpose}

The objective of the research was to investigate the relation between adult learners' cognitive learning strategies and their psychosocial employability attributes. In light of the importance of encouraging lifelong learning attitudes and behaviours in today's employees (Tshilongamulenzhe, 2012) and the importance attached to their psychosocial employability attributes (Bezuidenhout, 2011; Fugate et al., 2004; Guzman \& Choi, 2013) in today's more turbulent workplace, the present research seems timely and important. Both the notion of cognitive learning strategies and psychosocial employability attributes are seen as important positive coping or adaptive resources needed to obtain success in anxiety-provoking situations (Bezuidenhout, 2011; Fugate et al., 2004; Moneta et al., 2007; Williams 
et al., 2004). By investigating the relationship between adult learners' cognitive learning strategies and their psychosocial employability attributes, the present research endeavoured to contribute to the employability and adult training and learning literature. More specifically, the research was interested in answering the following research question:

Do the cognitive learning strategies of adult learners significantly explain their psychosocial employability attributes?

The classical conservation of resources theory (Hobfoll, 1989) posits in this regard that humans have a basic drive towards the maintenance, conservation and accumulation of resources and that these resources act as buffers against and reduce the adverse consequences of stress responses (Bakker \& Demerouti, 2007; Tuckey \& Hayward, 2011). Consequently, it was expected that adult learners' preferred learning strategies (as a set of cognitive coping resources) would strengthen the adaptive capacities represented by their psychosocial employability attributes. Moreover, training and educational research emphasises the importance of studying cognitive processes in interaction with motivational and self-regulative behaviours (Heikkilä, Niemivirta, Nieminen \& Lonka, 2011; Rozendaal, Minneart \& Boekaerts, 2001). Whereas learning and learning strategies are seen as cognitive processes (Rozendaal et al., 2001; Williams et al., 2004), psychosocial employability attributes are seen as core self-evaluations and self-regulative behaviours that are metacognitively guided and that are at least partially intrinsically motivated and to some extent strategically employed in the management of one's employability (Bezuidenhout, 2011).

\section{Literature review \\ Cognitive learning strategies}

The notion of cognitive learning strategies is based on the research conducted by Williams et al., (2004) on the behavioural strategies that learners adopt when preparing for formal assessment situations such as, for example, an examination. The cognitive learning strategies framework of Williams et al. (2004) is anchored in Carl Jung's (1921) theory of psychological type and the personality type theory of Myers and Briggs (Myers, McCaulley, Quenk \& Hammer, 2003), which is an extension of Jung's theory. Jung identifies two ways in which the mind functions in processing information (perception) and making decisions (judgment) and two attitudes toward life that create different lifestyles (extraversion and introversion). Williams et al. assert that the preferred cognitive learning strategies learners frequently adopt can be related to the inherent tendencies (preferences) underpinning the cognitive functions and attitudes of the personality types described by Myers and Briggs (Myers et al., 2003).

Individuals can take in or perceive information by preferring to deal with factual, practical information that they obtain through their senses (called sensing) or by intuitively trusting information that they receive from an unconscious processing of the relationship and patterns that arise out of the facts and details (called intuition). In terms of the judging function, individuals may prefer to use the thinking process and be objective and analytical when making a decision. Information is also presented in an intellectual manner. Individuals may also prefer to make decisions based on what they personally value, like or dislike and believe to be important to themselves and to others (Myers et al., 2003). Research shows that perceiving types prefer tasks that require the use of the right hemisphere of the brain (going with the flow and working at random), whilst judging types prefer left hemisphere learning tasks and use drills, games, fact retention, goal setting and methodical study to focus on learning content (Myers et al., 2003; Williams et al., 2004).

Williams et al. (2004) found that perceiving types may tend to adopt open-ended, spontaneous strategies. Adult learners using an open-ended learning approach tend to prefer flexibility and less structured activities such as, for example, exploring ideas and generating options and possibilities, being curious and interested in gathering more information, finding information from a variety of sources, planning as little as possible so as not to miss spontaneous opportunities, adapting easily to changing learning situations and modifying and changing projects as they evolve (Williams et al., 2004). Perceiving types may also tend to adopt either factual practical learning strategies or abstract, theoretical strategies. Learners with a strong preference for factual, practical strategies are drawn to hands-on activities, dealing with real data and facts and finding practical applications for learning. They further prefer to set short-term practical learning goals and build on existing knowledge (Williams et al., 2004). On the other hand, learners with a strong preference for abstract theoretical strategies enjoy grasping new ideas and possibilities, integrating information from a variety of sources and learning about theories and models. They tend to persist with complex learning material until they achieve understanding. They focus on organising information conceptually, focusing their learning on generalisations, abstract ideas and concepts and seeing trends and patterns in facts and data. They also prefer setting long-term learning goals and originating and innovating new ways of thinking about learning themes and situations (Williams et al., 2004).

Judging types may tend to prefer organised planned strategies and may be drawn to activities such as, for example, using study time efficiently, seeking order and being methodical, making and following plans and schedules, taking charge, coordinating actions and achieving results, defining manageable, achievable results, seeking clear learning objectives and timelines and deciding and moving forward in the pursuit of getting things done (Williams et al., 2004). Learners with a judging preference also tend to adopt either analytical, logical strategies or personally valued learning strategies. Learners who prefer an analytical, logical learning approach tend to judge information, rather than simply accepting it, and place information into a logical framework to increase understanding. Analytical, logical strategies entail examining and evaluating data and data trends, looking 
for cause and effect relationships, finding logical reasons for learning, debating and critiquing what is learned and considering logical consequences and implications (Williams et al., 2004). Learners with a strong preference for personally valued strategies demonstrate a subjective and situational cognitive learning approach. They tend to identify personal reasons for learning the material, relate what is being learned to personal situations and needs and ensure the learning will benefit or meet the needs of others. They enjoy learning that requires them to use their unique talents, characteristics or abilities. Their personal likes and dislikes also tend to influence the learning process (Williams et al., 2004).

The lifestyle attitudes relate to the type of environment that individuals find energising (Williams et al., 2004). Some individuals are energised by external experiences (called extraverts). Extraverts are attracted to action-taking and socialising (Kummerow \& Quenk, 1992). On the other hand, some individuals are more energised by internal experiences (called introverts). They are attracted to thoughtful, reflective, intimate activities (Myers et al., 2003; Williams et al., 2004). Research shows that extraverted learners work best when actively involved with external stimuli and that they may be drained by the intense, isolated work that studying requires. They therefore may tend to need breaks that allow them to interact with their environment. Introverts, on the other hand, need more quiet and freedom from distraction in order to concentrate (Myers et al., 2003). Williams et al. (2004) found that extraverted learners adopt environmentally interactive strategies. They prefer to discuss facts or ideas with others and build understanding about something by talking and thinking aloud. Learners who prefer environmentally interactive learning strategies tend to act immediately on what is being learned and learn by trying things out, researching information by contacting people and working on more than one thing at a time (Williams et al., 2004). On the other hand, learners who prefer an environmentally reflective approach to their learning find it helpful to explore the learning material in depth and use deep reflection when learning. Environmentally reflective learning strategies involve getting information as far ahead of time as possible, listening carefully, building understanding by thinking about information, working on one thing at a time, concentrating for extended periods of time and researching information by reading, listening and observing (Williams et al., 2004).

Sternberg (1997) posits in his theory of mental selfgovernment that people tend to have different ways of managing their own activities and that they tend to choose styles they are most comfortable with when they interact with environments or people. The theory of self-government explains why adult learners adopt different cognitive styles when engaging with learning or study activities (Liu, Magjuka \& Lee, 2008). Research provides evidence that some individuals tend to adopt a global cognitive style featuring broad-ranging global thinking or a local style characterised by detailed, local thinking, which focuses on a narrow range. Thinking styles may range from internal styles featuring introverted, task-oriented thinking and preferences for working alone to external styles characterised by extraverted, people-oriented, socially sensitive styles and preferences (Liu et al., 2008; Sternberg, 1997). Research has further shown that cognitive styles and cognitive learning strategies are related to learners' academic achievement (Liu et al., 2008; Williams et al., 2004; Zhang, 2004). Research also provides evidence that learners' preferred cognitive learning strategies and styles influence their level of achievement and that adult learners differ in terms of their success at taking formal assessments or examinations (Holtbrügge \& Mohr, 2010; Naimie, Siraj, Abuzaid \& Shagholi, 2010; Ng, Pinto \& Williams, 2011).

\section{Psychosocial employability attributes}

Psychosocial employability attributes are an aspect of individuals' self-regulatory capacities that promote adaptive cognition, behaviour and affect and enhance an individual's suitability for appropriate and sustained employment opportunities (Bezuidenhout, 2011; Potgieter, Coetzee \& Masenge, 2012; Fugate et al., 2004). Managing one's continued employability requires a range of attributes (dispositions, values, attitudes and skills) that promote proactive adaptability in changing environments and the likelihood of obtaining career success (Hamtiaux, Houssemand \& Vrignaud, 2013). In an attempt to elucidate the psychosocial self-regulatory capacities and self-evaluations individuals require for managing their employability, Bezuidenhout (2011) identified eight core psychosocial attributes based on an extensive literature review on the topic. These attributes are labelled as career self-management, career resilience, cultural competence, entrepreneurial orientation, sociability, self-efficacy, proactivity and emotional literacy. Career self-management is the individual's ability to sustain employability through constant learning, problemsolving and decision-making and career planning and management efforts (Schreuder \& Coetzee, 2011). Career resilience is a personal disposition that facilitates a high degree of adaptability, flexibility, self-confidence and competence, regardless of adverse career circumstances (Bezuidenhout, 2011). Chiaburu, Baker and Pitariu (2006) found career resilience to be positively associated with proactive personality and self-management behaviours. Cultural competence is the competence to grasp, reason and behave successfully in culturally diverse circumstances. Entrepreneurial orientation is a preference for innovation, creativity and autonomy in exploiting opportunities in the career environment, a propensity to take risks and a need for achievement (Bezuidenhout, 2011). Sociability (capacity to network with and build social contacts), self-efficacy (the belief in one's ability to successfully cope in a variety of career environments), proactivity (taking initiative in improving existing circumstances or creating more advantageous ones) and emotional literacy (the ability to accept and express a range of emotions that facilitate career adaptive behaviours) are core positive self-evaluations that are deemed important for sustaining one's employability (Bezuidenhout, 2011; Potgieter, 2012). 
The hypothesised relationship between adult learners' cognitive learning strategies and their psychosocial employability attributes is approached from the perspective of Bandura's $(1978,1989,1999)$ general social cognitive theory and in particular the model of emergent interactive agency (Bandura, 1978, 1989). Broadly speaking, this model focuses on the interplay between action, cognitive, affective and other personal factors and environmental events. The human mind is seen as generative, creative, proactive and self-reflective. Knowledge structures, representing the models, rules and strategies of effective action, serve as cognitive guides for the construction of complex patterns of behaviour (Bandura, 1999). Individuals are seen to have some active control over both their environments and themselves by drawing on their knowledge and cognitive and behavioural skills to produce desired results (Bandura, 1989; Converse, Pathak, DePaulHaddock, Gotlib \& Merbedone, 2012). According to Bandura (1999), the cognitive capacities of individuals enable them to profit extensively from learning and life experiences. People's psychosocial attributes have been related to key selfevaluations and agentic processes and resources that enable them to manage their employability (Bezuidenhout, 2011; Fugate et al., 2004), control and influence their environment (Hobfoll, Johnson, Ennis \& Jackson, 2003; Rottinghaus, Buelow, Matyja \& Schneider, 2012), successfully cope with job demands, attain goals and achieve personal growth and development (Demerouti, Bakker, Nachreiner \& Schaufeli, 2001) and solve the unfamiliar, complex and illdefined problems presented by current and anticipated developmental vocational tasks and transitions and traumas in occupational roles (Savickas \& Porfeli, 2012). Proactive individuals seem to be oriented toward learning and development (Converse et al., 2012) and are more likely to engage in self-enhancing behaviours such as pursuing further education, training and learning in order to advance their careers (Seibert, Crant \& Kraimer, 1999) and develop new skills (Fuller \& Marler, 2009). Coetzee and Botha (2013) also found that adult learners' cognitive learning strategies significantly predict their sense of self-directedness, success orientation and intrinsic motivation to study and learn.

\section{Potential value-add by the study}

Hirischi, Lee, Porfeli and Vondraeck (2013) posit that the increased self-directedness of contemporary careers necessitates that employees take charge of their own career development and develop the proactive career management behaviours they need for enhancing their employability. Understanding the role of cognitive learning strategies in either enhancing or lowering adult learners' capacity to demonstrate the psychosocial attributes they need to proactively manage their employability therefore seems to be important. Assessing the cognitive learning strategies learners use to prepare for formal types of assessment and how these relate to their psychosocial employability attributes could be invaluable to learning practitioners to help improve the learning performance and employability of adult learners (Coetzee \& Botha, 2013; Williams et al., 2004).

\section{What will follow}

In the next section, the research design for this study will be elaborated on and the research approach and method will be covered. The results will then be presented and the findings discussed. The article concludes with a brief outline of the most important conclusions, limitations of the research design and recommendations for possible future research initiatives.

\section{Research design Research approach}

The present study is exploratory in nature as the variables under investigation appear to have commanded little research attention in South Africa up to now. A quantitative, cross-sectional survey was utilised to collect primary data, involving adult learners enrolled in further studies in the economic and management sciences field.

\section{Method}

\section{Measures \\ Participants}

A stratified proportional random sample $(N=1102)$ of undergraduate adult learners at a South African distance learning higher education institution participated in the study. The sample was stratified to proportionally represent the various fields of study in the economic and management sciences per course, level of study (1st-3rd year), school and department. The sample predominantly consisted of black students (92\%) between the ages of 18 and 40 years (88\%); $63 \%$ were female and $57 \%$ were employed.

\section{Measuring instruments}

Cognitive learning strategies were measured by the examination preparation style inventory (Williams et al., 2004). The examination preparation style inventory (EPI) is a self-report measure that identifies the cognitive-behavioural strategies (115 items clustered into eight subscales) that adult learners use when preparing for formal assessments or examinations. A five-point Likert-type scale format is used to measure the respondents' responses to each item. The eight subscales are: environmentally interactive, environmentally reflective, factual practical, abstract theoretical, analytical logical, personally valued, organised planned and openended spontaneous cognitive learning strategies. Overall, research by Williams et al. (2004) provides supportive evidence of the validity and reliability of the EPI as a measure of cognitive learning strategies. Test-retest reliability coefficients for the eight scales ranged between 0.70 and 0.87 (Williams et al., 2004). The EPI shows proven predictive validity with students' grade point average (GPA). In terms of the present study, Cronbach's alpha coefficients (internal consistency reliabilities) ranging between 0.70 and 0.85 were obtained.

Psychosocial employability attributes were measured by the employability attributes scale (Bezuidenhout \& Coetzee, 
2010). The employability attributes scale (EAS) is a selfrated, multi-factorial measure that contains 56 items and eight sub-scales: career self-management (11 items), cultural competence (5 items), self-efficacy (6 items), career resilience (6 items), sociability (7 items), entrepreneurial orientation (7 items), proactivity (7 items), and emotional literacy (7 items). Respondents are required to rate each item on a six-point Likert-type scale. An exploratory factor analysis (Coetzee, 2010) provided evidence that the EAS items meet the psychometric criteria of construct validity. Cronbach's alpha (internal consistency) reliability coefficients for each subscale ranged between 0.78 and 0.90 (Coetzee, 2010). In terms of the present study, Cronbach's alpha coefficients (internal consistency reliabilities) ranging between 0.81 and 0.90 were obtained.

\section{Procedure and ethical considerations}

Ethical clearance and permission to conduct the study were obtained from the management and research ethics committee of the higher education institution that participated in the study. Questionnaires were mailed to a stratified proportional random sample $(N=4850)$ of students enrolled for studies in the economic and management sciences field. The sample was stratified by module, level of study, department and school. The survey yielded 1102 useable questionnaires (response rate of $23 \%$ ). Each questionnaire included a covering letter to obtain informed consent from the participants to use their responses for research purposes only. The covering letter explained the purpose of the research, procedure, potential benefits, confidentiality, anonymity, voluntary participation and withdrawal. Participants were requested to complete the questionnaires and return them by mail to the researchers using an enclosed return envelope.

\section{Statistical analysis}

Descriptive statistics (means, standard deviations and Cronbach's alpha coefficients), canonical correlations and standard multiple regression statistical analysis were performed. In line with guidelines by Hair, Black, Babin and Anderson (2010), the cut-off criteria for canonical factorial loadings ( $\geq 0.30$ ) were used to interpret the relative importance of the canonical loadings. The $r^{2}$ type effect size

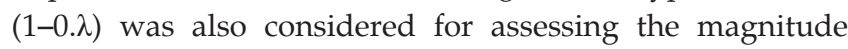
of the overall correlational relationships between the two variates of a canonical function and the practical significance of the predictive ability of the canonical relationship (Hair et al., 2010). In terms of the multiple regression analysis, $R^{2}$ values of below 0.12 (small practical effect), between 0.13 and 0.25 (medium practical effect) and above 0.26 (large practical effect) $(F p \leq 0.05)$ (Cohen, 1992) were considered in the interpretation of the results. Prior to conducting the various regression analyses, collinearity diagnostics were examined to ensure that zero-order correlations were below the level of concern $(r \geq 0.80)$, that the variance inflation factors did not exceed 10, that the condition index was well below 15 and that the tolerance values were close to 1.0 (Field, 2009).

\section{Results \\ Means, standard deviations and internal consistency reliabilities}

Table 1 shows that the participants obtained the highest mean scores for the EPI variables associated with the abstract theoretical $(M=3.14 ; S D=0.54)$, factual practical $(M=3.04 ; S D=0.54)$ and organised planned $(M=3.02$; $S D=0.52)$ strategies. The environmentally interactive cognitive learning strategies were the least preferred by the participants $(M=2.83 ; S D=0.63)$. In terms of the EAS, the participants obtained the highest mean scores for career selfmanagement $(M=4.80 ; S D=0.82)$ and self-efficacy $(M=4.80$; $S D=0.79)$. The participants obtained the lowest mean scores for sociability $(M=4.27$; $S D=0.92)$.

\section{Correlations}

As shown in Table 1, the correlations between the EPI and EAS variables ranged between 0.11 and 0.34 (small to moderate practical effect; $p=0.00$ ). All correlations were in the expected direction (positive). Only emotional literacy did not correlate significantly with the open-ended spontaneous cognitive learning strategy. The zero-order correlations were well below the threshold level of concern $(r \geq 0.80)$ about multicollinearity.

\section{Canonical correlation analysis}

Canonical correlation analysis was used to further understand the relations between the two sets of zero-order correlations (EPI and EAS). The canonical correlation analysis (see Table 2) assessed the overall statistical relationship between the EPI variables (as a composite set of multiple independent variables of the cognitive learning strategies construct) and the EAS variables (as a composite set of multiple dependent variables of the psychosocial employability attributes construct). The first function of the canonical model was statistically significant and of relevance to the present research (overall $R c^{2}=0.18 ; F(p)=3.98, p=0.0001$; Wilks's lambda: $\lambda=0.76 ; p=0.0001 ; r^{2}$ type effect size: $1-0 . \lambda=0.24$; moderate practical effect). Overall, the results indicated that the EPI cognitive learning strategies were significantly related to the EAS psychosocial employability attributes. The Wilks's lambda represents the amount of variance not shared between the variable sets (inverse effect size). The $r^{2}$ type effect size was $0.24(1-0 . \lambda)$, which indicates that the full model explained a moderate proportion $(24 \%)$ of the variance shared between the two variable sets. As illustrated in Table 2 , the first canonical function contributed $18 \%\left(R c^{2}=0.18\right.$; moderate practical effect) of the explained variation. Both the EPI and EAS variables were positively correlated with their respective canonical function. The abstract theoretical $\left(R c=0.91\right.$; coefficient weight $\left.\mathrm{c}_{\mathrm{c}}=0.85\right)$ and factual practical $\left(R c=0.80\right.$; coefficient weight $\left.t_{c}=0.25\right)$ cognitive learning strategies contributed the most in explaining the variance in the cognitive learning strategies construct. The career self-management $\left(R c=0.94\right.$; coefficient weight $\left._{c}=0.49\right)$ and proactivity $\left(R c=0.90\right.$; coefficient weight $\left._{c}=0.19\right)$ attributes 


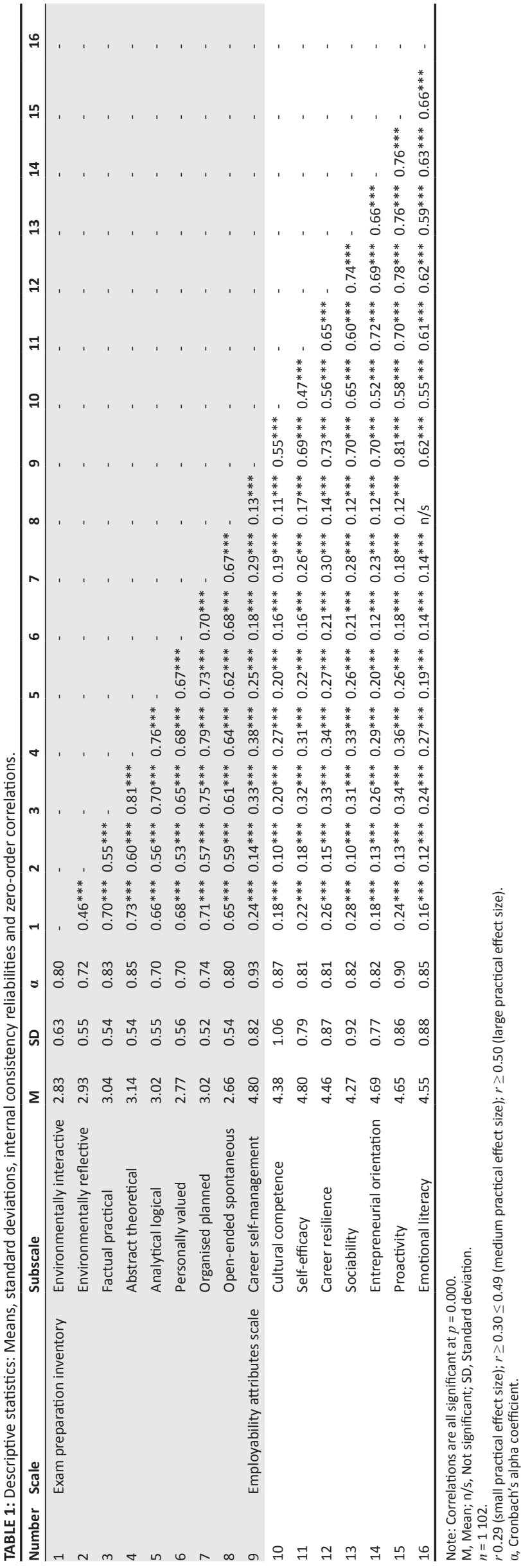

contributed the most in explaining the variance in the psychosocial employability attributes construct.

The results of the cross-correlations (see Table 2) between the cognitive learning strategies (EPI) and the psychosocial employability attributes (EAS) showed that the abstract theoretical cognitive learning strategies exhibited the highest correlation with the psychosocial employability attributes canonical variate construct and explained $39 \%\left(R c^{2}=0.39\right.$; large practical effect) of the variance in the psychosocial employability attributes variate. Career self-management correlated the highest with the cognitive learning strategies canonical variate, explaining $40 \%\left(R c^{2}=0.40\right.$; large practical effect) of the variance in the cognitive learning strategies variate. Overall, the results suggest that the abstract theoretical and factual practical cognitive learning strategies are, relative to the other cognitive learning strategies, the most useful indicators of the participants' overall level of psychosocial employability attributes.

\section{Multiple regression analysis}

As reflected in Table 3, the multiple regression analysis on each of the eight EAS subscales produced significant predictive models from the EPI predictor variables. Table 3 reports only the significant EPI predictor variables. Model 1 shows that the abstract theoretical cognitive learning strategies significantly and positively contributed in explaining the variance in career self-management $(\beta=0.36 ; p=0.001)$. The open-ended spontaneous cognitive learning strategies significantly and negatively contributed in explaining the variance in career self-management $(\beta=-0.17 ; p=0.002)$. Overall, these two variables contributed significantly in predicting the participants' levels of career self-management $\left(R^{2}=0.15\right.$; medium practical effect; $\left.p \leq 0.001\right)$. Model 2 shows that the abstract theoretical $(\beta=0.11 ; p=0.002)$ cognitive learning strategies significantly and positively contributed in explaining the variance in cultural competence. The model explains $8 \%\left(R^{2}=0.08\right.$; small practical effect; $\left.p=0.01\right)$ of the variance in cultural competence.

Model 3 shows that the abstract theoretical $(\beta=0.11$; $p=0.002)$ and factual practical $(\beta=0.07 ; p=0.01)$ cognitive learning strategies significantly and positively contributed in explaining the variance in self-efficacy. Overall, these two variables contributed significantly in predicting the participants' levels of self-efficacy $\left(R^{2}=0.10\right.$; small practical effect; $p \leq 0.001$ ). As reflected in Table 3, Model 4 shows that the abstract theoretical $(\beta=0.11 ; p=0.001)$ and factual practical ( $\beta=0.06 ; p=0.04$ ) cognitive learning strategies also significantly and positively contributed in explaining the variance in career resilience. The open-ended spontaneous cognitive learning strategies significantly and negatively contributed in explaining the variance in career resilience $(\beta=-0.09 ; p=0.003)$. Overall, these three variables contributed significantly in predicting the participants' levels of career resilience $\left(R^{2}=0.12\right.$; small practical effect; $\left.p \leq 0.001\right)$.

Model 5 shows that the abstract theoretical $(\beta=0.17$; $p=0.001)$ cognitive learning strategies significantly and 
TABLE 2: Standardised canonical correlation analysis results for the first canonical function variates - EPI (independent variables) versus EAS (dependent variables).

\begin{tabular}{|c|c|c|c|c|}
\hline \multirow[t]{2}{*}{ Variate } & \multirow[t]{2}{*}{ Variables } & \multicolumn{3}{|c|}{ Function 1} \\
\hline & & $\begin{array}{l}\text { Canonical coefficients } \\
\text { (weights) }\end{array}$ & Canonical loading $(R c)$ & $\begin{array}{c}\text { Canonical } \\
\text { cross-loadings (\%) }\end{array}$ \\
\hline \multirow{6}{*}{$\begin{array}{l}\text { Set of independent variables (EPI): } \\
\text { Cognitive learning strategies } \uparrow\end{array}$} & Environmentally interactive & -0.05 & 0.61 & 0.26 \\
\hline & Factual practical & 0.25 & 0.80 & 0.34 \\
\hline & Abstract theoretical & 0.85 & 0.91 & 0.39 \\
\hline & Analytical logical & 0.03 & 0.64 & 0.27 \\
\hline & Organised planned & 0.09 & 0.69 & 0.29 \\
\hline & Open-ended spontaneous & -0.33 & 0.29 & 0.12 \\
\hline \multirow{7}{*}{$\begin{array}{l}\text { Set of dependent variables (EAS): } \\
\text { Psychosocial employability attributes }{ }^{\text {b }}\end{array}$} & Career self-management & 0.49 & 0.94 & 0.40 \\
\hline & Cultural competence & 0.07 & 0.67 & 0.28 \\
\hline & Self-efficacy & 0.13 & 0.76 & 0.32 \\
\hline & Career resilience & 0.12 & 0.83 & 0.35 \\
\hline & Sociability & 0.18 & 0.84 & 0.35 \\
\hline & Proactivity & 0.19 & 0.90 & 0.38 \\
\hline & Emotional literacy & 0.08 & 0.74 & 0.31 \\
\hline
\end{tabular}

Overall $R c^{2}=0.18 ; \mathrm{F}(p)=3.98(p<0.0001) ; d f=72 ; 6084.3$; Wilks's lambda $(\lambda)=0.76 ; r^{2}$ type effect size: $1-0 . \lambda=0.24$ (moderate practical effect).

$R c^{2} \leq 0.12$ (small practical effect size); $R c^{2} \geq 0.13 \leq 0.25$ (moderate practical effect size); $\mathrm{Rc}^{2} \geq 0.26$ (large practical effect size); $n=1102$.

EPI, Exam preparation inventory; EAS, Employability attributes scale.

$\dagger$, Independent canonical variate: average canonical loading $R c^{2}=0.40$; Redundancy index $=0.07$.

\pm Dependent canonical variate: average canonical loading $R c^{2}=0.65$; Redundancy index $=0.12$.

TABLE 3: Significant multiple regression analysis: EPI (independent variables) versus EAS (dependent variables).

\begin{tabular}{|c|c|c|c|c|c|c|}
\hline Number & Model & Variable & $\beta$ & $p$ & $F$ & Adjusted $R^{2}$ \\
\hline \multirow[t]{2}{*}{1} & \multirow{2}{*}{$\begin{array}{l}\text { Career self-management } \\
\text { (EAS) }\end{array}$} & Abstract theoretical & 0.36 & 0.001 & $21.27 * * *$ & $0.15 \$$ \\
\hline & & Open-ended spontaneous & -0.17 & 0.002 & & \\
\hline 2 & $\begin{array}{l}\text { Cultural competence } \\
\text { (EAS) }\end{array}$ & Abstract theoretical & 0.15 & 0.001 & $10.50^{*}$ & $0.08 \dagger$ \\
\hline \multirow[t]{2}{*}{3} & \multirow{2}{*}{$\begin{array}{l}\text { Self-efficacy } \\
\text { (EAS) }\end{array}$} & Factual practical & 0.07 & 0.01 & $13.81 * * *$ & $0.10 \dagger$ \\
\hline & & Abstract theoretical & 0.11 & 0.002 & & \\
\hline \multirow[t]{3}{*}{4} & \multirow{3}{*}{$\begin{array}{l}\text { Career resilience } \\
\text { (EAS) }\end{array}$} & Factual practical & 0.06 & 0.04 & $15.99 * * *$ & $0.12 t$ \\
\hline & & Abstract theoretical & 0.11 & 0.001 & & \\
\hline & & Open-ended spontaneous & -0.09 & 0.003 & - & - \\
\hline \multirow[t]{3}{*}{5} & \multirow{3}{*}{$\begin{array}{l}\text { Sociability } \\
\text { (EAS) }\end{array}$} & Environmentally reflective & -0.09 & 0.01 & $16.99 * * *$ & $0.12 \ddagger$ \\
\hline & & Abstract theoretical & 0.17 & 0.001 & & \\
\hline & & Open-ended spontaneous & -0.12 & 0.002 & & \\
\hline \multirow[t]{2}{*}{6} & \multirow{2}{*}{$\begin{array}{l}\text { Entrepreneurial orientation } \\
\text { (EAS) }\end{array}$} & Abstract theoretical & 0.17 & 0.001 & $12.58 * * *$ & $0.09 \dagger$ \\
\hline & & Open-ended spontaneous & -0.06 & 0.05 & & \\
\hline \multirow[t]{4}{*}{7} & \multirow{4}{*}{$\begin{array}{l}\text { Proactivity } \\
\text { (EAS) }\end{array}$} & Environmentally reflective & -0.06 & 0.05 & $18.90 * * *$ & $0.14 \ddagger$ \\
\hline & & Factual practical & 0.10 & 0.004 & & \\
\hline & & Abstract theoretical & 0.20 & 0.001 & & \\
\hline & & Open-ended spontaneous & -0.10 & 0.01 & & \\
\hline \multirow[t]{2}{*}{8} & \multirow{2}{*}{$\begin{array}{l}\text { Emotional literacy } \\
\text { (EAS) }\end{array}$} & Abstract theoretical & 0.16 & 0.001 & $12.40 * * *$ & $0.09 \dagger$ \\
\hline & & Open-ended spontaneous & -0.15 & 0.001 & & \\
\hline
\end{tabular}

$n=1102$

${ }^{* * *}, p \leq 0.001 ; * *, p \leq 0.01 ; *, p \leq 0.05$

$\dagger, R^{2} \leq 0.12$ (small practical effect size); $\ddagger, R^{2} \geq 0.13 \leq 0.25$ (medium practical effect size); $\S, R^{2} \geq 0.26$ (large practical effect size).

$F$, function; $\beta$, standardised regression coefficient; EPI, Exam preparation inventory; EAS, Employability attributes scale.

Note: Collinearity statistics were as follows: Tolerance $\leq 1.0 ;$ VIF $>1.0<1.1$; Condition index $>1<4$.

positively contributed in explaining the variance in sociability. The open-ended spontaneous $(\beta=-0.12 ; p=0.002)$ and environmentally reflective $(\beta=-0.09 ; p=0.01)$ cognitive learning strategies significantly and negatively contributed in explaining the variance in sociability. Overall, these three variables contributed significantly in predicting the participants' levels of sociability $\left(R^{2}=0.12\right.$; small practical effect; $p \leq 0.001)$. As seen in Table 3, in Model 6, the abstract theoretical ( $\beta=0.11 ; p=0.002)$ cognitive learning strategies significantly and positively contributed in explaining the variance in entrepreneurial orientation, whilst the openended spontaneous $(\beta=-0.06 ; p=0.05)$ cognitive learning strategies negatively contributed in explaining the variance. The model explains 9\% $\left(R^{2}=0.09\right.$; small practical effect; $p=0.001)$ of the variance in entrepreneurial orientation. In Model 7 , the abstract theoretical $(\beta=0.20 ; p=0.001)$ and factual practical $(\beta=0.10 ; p=0.004)$ cognitive learning strategies significantly and positively contributed in explaining the variance in proactivity. The open-ended spontaneous $(\beta=-0.10 ; p=0.01)$ and environmentally reactive $(\beta=-0.06$; $p=0.05)$ cognitive learning strategies negatively contributed in explaining the variance. The model explains $14 \%$ $\left(R^{2}=0.14\right.$; medium practical effect; $\left.p=0.001\right)$ of the variance in proactivity. Finally, in Model 8, the abstract theoretical 
$(\beta=0.16 ; p=0.001)$ cognitive learning strategies significantly and positively contributed in explaining the variance in emotional literacy. The open-ended spontaneous $(\beta=-0.15$; $p=0.001)$ cognitive learning strategies negatively contributed in explaining the variance. The model explains $9 \%\left(R^{2}=0.09\right.$; small practical effect; $p=0.001)$ of the variance in emotional literacy.

\section{Discussion}

The objective of the research was to investigate the relation between adult learners' cognitive learning strategies and their psychosocial employability attributes. Overall, the canonical results suggested that the abstract theoretical and factual practical cognitive learning strategies are, relative to the other cognitive learning strategies, the most useful indicators of the participants' overall level of psychosocial employability attributes, and especially their levels of career self-management and proactivity. The multiple regression analysis further investigated the overall relationship and confirmed the explanatory role of the abstract theoretical learning strategies in terms of the participants' levels of psychosocial employability attributes. The highest beta weights were also obtained in terms of the career selfmanagement and proactivity attributes.

The abstract theoretical and factual practical learning strategies are related to the information-seeking and information-using preferences of the participants (Williams et al., 2004). It appears from the results that a preference for abstract theoretical information significantly increased the participants' proactivity and sense of agency in managing their careers. Career self-management entails a sense of autonomy and perceived controllability over one's life and situation. One easily recognises the skills needed to be successful in one's career and the actions necessary in order to achieve career goals (Bezuidenhout, 2011; Schreuder \& Coetzee, 2011). Abstract theoretical learning strategies entail having a preference for setting broad long-term learning goals, integrating information from a variety of sources and organising it conceptually, grasping new ideas and possibilities and generating new ways to think about learning themes and situations (Williams et al., 2004). These cognitive learning strategies appear to have strengthened the participants' drive, proactivity and confidence in conceptually organising the information they need to manage and realise their personal career objectives. Coetzee and Botha (2013) found that learning strategies relating to the way adult learners gather and use information (abstract theoretical and factual practical) significantly strengthen their sense of self-directedness, success orientation, intrinsic motivation to engage in learning activities and utilisation of learning resources. Learners who prefer using abstract theoretical learning strategies also tend to persevere in successfully completing complex learning material (Williams et al., 2004). Having the confidence and determination to pursue and achieve set career goals and continuously engage in development activities to achieve career goals are also typical of proactive career self-management behaviour (Bezuidenhout, 2011; De Vos \& Soens, 2008; Schreuder \& Coetzee, 2011).

The results further suggest that the factual practical learning strategies, which entail a preference to engage in hands-on activities, relating information to realities and past information, building on existing knowledge and finding practical application for learning (Williams et al., 2004), significantly increased the participants' self-efficacy, career resilience and proactivity. Self-efficacy beliefs help determine how much effort people will expend on an activity, how long they will persevere when confronting obstacles and how resilient they will prove to be in the face of adverse and stressful situations: the higher the sense of self-efficacy, the greater the effort, persistence and resilience (Coetzee \& Oosthuizen, 2013; Pajares, 1996). The positive relation between the participants' factual practical learning strategies and their self-efficacy, career resilience and proactivity may be attributed to the proposition made by Dooley, Linden and Dooley (2005) that learning seems to improve when learners have the opportunity to practise and experiment with what and how they learn. Experiential learning increases learners' levels of active study engagement (Robinson, 2006), which, in turn, has been shown to enhance their confidence in their abilities to successfully perform and persevere in complicated situations (Coetzee \& Oosthuizen, 2013). Using practical factual information to solve problems and make decisions that apply to real-world situations also increases adult learners' sense of self-directedness and intrinsic learning motivation (Coetzee \& Botha 2013). Self-directed learners are known to take responsibility for their learning and to feel confident about their ability to be successful (Botha, 2012; De Bruin \& De Bruin, 2011). Fugate and Kinicki (2008) found positive self-evaluations to be characteristic of resilient individuals who are also regarded to be highly employable. Research by Bowling, Wang and Li (2012) indicates that positive self-evaluations enhance individuals' general level of initiative and beliefs about their general level of competence.

It is interesting to observe that the open-ended spontaneous learning strategies (i.e. preferring flexibility, variety and less structured learning activities) explained lower levels in the participants' career self-management, career resilience, sociability, entrepreneurial orientation, proactivity and emotional literacy. The findings seem to corroborate research by Coetzee and Botha (2013) indicating that an open-ended spontaneous learning approach lowers adult learners' success orientation, that is their confidence and sense of responsibility in resolving learning obstacles (for example workload, obtaining needed information and meeting study or learning deadlines). People with an open-ended spontaneous learning style are generally energised just before examination time which may negatively affect their learning success and performance (Williams et al., 2004). 
The environmentally reflective learning strategies also explained lower levels of proactivity and sociability. Learners who prefer these learning strategies are generally more introverted and reflective in nature, and prefer to learn and study on their own and at their own pace (Myers et al., 2003; Williams et al., 2004), which, in turn, may explain the participants' lower levels of sociability and proactivity. On the other hand, learners who prefer environmentally interactive learning strategies have been found to act immediately on what is being learned and engage with others to enhance their learning (Williams et al., 2004).

\section{Conclusion Implications for practice}

The present study provides new, original insights and knowledge regarding the explanatory power of adult learners' cognitive learning strategies in terms of their levels of psychosocial employability attributes. Overall, it is concluded that the cognitive learning strategies associated with the participants' preferred way of seeking and using information (abstract theoretical and factual practical) when preparing for an examination or formal type of assessment are most likely to strengthen their psychosocial employability attributes, especially their career self-management and proactivity. However, following an open-ended spontaneous and environmentally reflective approach toward preparing for a formal assessment or examination may significantly lower adult learners' psychosocial employability attributes. There are several implications that can be drawn from these results regarding the design of formal learning and development programmes.

Firstly, the results of the study suggest that it will be useful for learning practitioners to integrate cognitive learning styles as one of the factors in designing learning and assessment activities in order to foster the psychosocial employability attributes adult learners need to manage their continued employability in the contemporary workplace. Adult learners participating in formal training and development programmes need to develop insight into how their cognitive learning strategies in preparing for an examination or formal type of assessment influence their ability to successfully and proactively manage their employability.

Secondly, although cognitive learning strategies represent relatively fixed ways of conceptualising and processing information, research evidence suggests that individuals may develop cognitive flexibility to improve their learning and performance (Liu et al., 2008; Sternberg, 1997; Williams et al., 2004). The findings of the present study imply that adult learners should be guided as to how to adopt a balance between the abstract theoretical and factual practical learning strategies when preparing for an examination or formal type of assessment. Learning practitioners should further ensure that a programme's learning and assessment design provides learners with the opportunity to engage in activities that draw on these information-seeking and information-using strategies. Such an approach to learning and assessment design may help to strengthen the learners' capacity for adopting the career self-management attitudes and self-enhancing behaviours they need to enhance their employability.

Thirdly, adult learners who prefer open-ended spontaneous learning strategies should be made aware of the implications of these approaches for their ability to manage their employability. They should be guided in terms of how to complement their preferred learning approach with a more organised planned approach in preparing for an examination or formal type of assessment. Finally, learners who prefer an environmentally reflective approach to their learning should be coached in terms of becoming more proactive in developing the social skills they need to manage their employability.

\section{Limitations and recommendations for future research}

The conclusions about the findings of the study need to be considered in light of a number of limitations, each suggestive of promising directions in the area of research into enhancing adult learners' ability to manage their learning performance and employability. Firstly, the study was cross-sectional in nature and thus the causal direction of relations between the variables cannot be ascertained. Longitudinal studies are needed to understand how adult learners' preferred cognitive learning strategies influence the development of psychosocial employability attributes and how these influence their ability to successfully manage their employability over time.

Secondly, the participants in this study were enrolled as distance learning students at first year to third year level undergraduate studies in the economic and management sciences field at one university. They were mostly early career black and female students. The findings can therefore not be generalised to other educational, occupational, age, race and gender contexts. Replication studies, using independent samples drawn from other contexts are recommended. Notwithstanding these limitations, the study contributed valuable new information in the light of the paucity of research into the cognitive learning strategies and psychosocial employability attributes of early career black and female adult learners in the South African context.

\section{Acknowledgements Competing interests}

The authors declare that they have no financial or personal relationship(s) that may have inappropriately influenced them in writing this article.

\section{Authors' contributions}

M.C. (University of South Africa) conducted the literature research, the data collection and statistical analysis and wrote up the report. I.L.P. (University of South Africa) assisted with the literature research and writing up the report. 


\section{References}

Avey, J.B., Reichard, R.J., Luthans, F., \& Mhatre, K.H. (2011). Meta-analysis of the impact of positive psychological capital on employee attitudes, behaviors, and performance. Human Resource Development Quarterly, 22(2), 127-152. http:// dx.doi.org/10.1002/hrdq.20070

Bakker, A.B., \& Demerouti, E. (2007). The job demands-resources model: State of the art. Journal of Managerial Psychology, 22, 309-328. http://dx.doi. org/10.1108/02683940710733115

Bandura, A. (1978). The self system in reciprocal determinism. American Psychologist, 33, 344-358. http://dx.doi.org/10.1037/0003-066X.33.4.344

Bandura, A. (1989). Human agency in social cognitive theory. American Psychologist, 44, 1175-1184. http://dx.doi.org/10.1037/0003-066X.44.9.1175

Bandura, A. (1999). Social cognitive theory: An agentic perspective. Asian Journal of Social Psychology, 2, 21-41. http://dx.doi.org/10.1111/1467-839X.00024

Bezuidenhout, M. (2011). The development and evaluation of a measure of graduate employability in the context of the new world of work. Unpublished master's dissertation, University of Pretoria, Pretoria, South Africa.

Bezuidenhout, M., \& Coetzee, M. (2010). Preliminary exploratory factor analysis: Student employability scale. Unpublished research report, Department of Industrial and Organisational Psychology, University of South Africa, Pretoria, South Africa.

Botha, J. (2012). Graduateness, self-directedness and employability. In M. Coetzee, J. Botha, N. Eccles, N. Holtzhausen, \& H. Nienaber (Eds.), Developing student graduateness and employability: Issues, provocations, theory and practical guidelines (pp. 385-402). Randburg, South Africa: Knowres.

Bowling, N.A., Wang, Q., \& Li, H.Y. (2012). The moderating effect of core selfevaluations on the relationship between job attitudes and organizational citizenship behavior. Applied Psychology: An International Review, 61(1), 97-113. $\mathrm{http}: / / \mathrm{dx}$. doi.org/10.1111/j.1464-0597.2011.00458.x

Chiaburu, D.S., Baker, V.L., \& Pitariu, A.H. (2006). Beyond proactive: What else matters for career self-management behaviors? Career Development International, 11(7), for career self-management behaviors? Career Developme
619-632. http://dx.doi.org/10.1108/13620430610713481

Choi, W., \& Jacobs, R.L. (2011). Influences of formal learning, personal learning orientation, and supportive learning environment on informal learning. Human Resource Development Quarterly, 22(3), 239-257. http://dx.doi.org/10.1002/ Resource Deve
hrdq. 20078

Coetzee, M. (2010). Preliminary factor analysis of the employability attributes scale. Unpublished research report, University of South Africa, Pretoria, South Africa.

Coetzee, M. (Ed.). (2013a). Practising training and development in South African organisations. (2nd edn.). Cape Town: Juta.

Coetzee, M. (2013b). A psychological career resources framework for contemporary career development. In M.Coetzee (Ed.), Psycho-social career meta-capacities. Dynamics of contemporary career development (pp. 87-122). Dordrecht, The Netherlands: Springer International.

Coetzee, M., \& Botha, J. (2013). Undergraduate students' self-directedness in relation to their examination preparation styles in Open Distance Learning. Progressio, 35(2), 34-57.

Coetzee, M. \& Oosthuizen, R.M. (2013). Examining the mediating effect of open distance learning students' study engagement in relation to their life orientation distance learning students' study engagement in relation to their
and self-efficacy. Journal of Psychology in Africa, 23(2), 235-242.

Cohen, J. (1992). Quantitative methods in psychology: A power primer. Psychological Bulletin, 112(1), 153-159. http://dx.doi.org/10.1037/0033-2909.112.1.155

Converse, P.D., Pathak, J., DePaul-Haddock, A.M., Gotlib, T., \& Merbedone, M. (2012). Controlling your environment and yourself: Implications for career success. Journal of Vocational Behavior, 80, 148-159. http://dx.doi.org/10.1016/j. jvb.2011.07.003

De Bruin, K., \& De Bruin, G.P. (2011). Development of the learner self-directedness in the workplace scale. South African Journal of Industrial Psychology, 37(1) 926-936.

Demerouti, E., Bakker, A.B., Nachreiner, F., \& Schaufeli, W.B. (2001). The job demandsresources model of burnout. Journal of Applied Psychology, 86, 499-512. http:// dx.doi.org/10.1037/0021-9010.86.3.499

De Vos, A., \& Soens, N. (2008). Protean attitude and career success: The mediating role of self-management. Journal of Vocational Behavior, 73, 449-456. http:// dx.doi.org/10.1016/j.jvb.2008.08.007

Dooley, K.E., Lindner, J.R., \& Dooley, L.M. (2005). Advanced methods in distance education. Hershey, PA: Information Science Publishing. http://dx.doi. org/10.4018/978-1-59140-485-9

Field, A. (2009). Discovering statistics using SPSS. (3rd edn.). London, England: Sage.

Fugate, M., \& Kinicki, A. (2008). A dispositional approach to employability Development of a measure and test of implications for employee reactions to organisational change. Journal of Occupational and Organizational Psychology, 81, 503-527. http://dx.doi.org/10.1348/096317907X241579

Fugate, M., Kinicki, A.J., \& Ashforth, B.E. (2004). Employability: A psycho-social construct, its dimensions and applications. Journal of Vocational Behavior, 65 14-38. http://dx.doi.org/10.1016/j.jvb.2003.10.005

Fuller, B., \& Marler, F.E. (2009). Change driven by nature: A meta-analytic review of the proactive personality literature. Journal of Vocational Behavior, 75(3), 329345. http://dx.doi.org/10.1016/j.jvb.2009.05.008

Guzman, A.B., \& Choi, K.O. (2013). The relations of employability skills to career adaptability among technical school students. Journal of Vocational Behavior, 82, 199-207. http://dx.doi.org/10.1016/j.jvb.2013.01.009
Hair, J., Black, W., Babin, B., \& Anderson, R. (2010). Multivariate data analysis. Englewood Cliffs, NJ: Pearson Education.

Hamtiaux, A., Houssemand, C., \& Vrignaud, P. (2013). Individuals and career adaptability: Comparing models and measures. Journal of Vocational Behavior 83, 130-141. http://dx.doi.org/10.1016/j.jvb.2013.03.006

Heikkilä, A., Niemivirta, M., Nieminen, J., \& Lonka, K. (2011). Interrelations among university students' approaches to learning, regulation of learning, and cognitive and attributional strategies: A person-oriented approach. Higher Education, 61 513-529. http://dx.doi.org/10.1007/s10734-010-9346-2

Hirschi, A., Lee, B., Porfeli, E.J., \& Vondraeck, F.W. (2013). Proactive motivation and engagement in career behaviours: Investigating direct, mediated, and moderated effects. Journal of Vocational Behavior, 83, 31-40. http://dx.doi.org/10.1016/j. jvb.2013.02.003

Hobfoll, S.E. (1989). Conservation of resources: A new attempt at conceptualizing stress. American Psychologist, 3, 513-524. http://dx.doi.org/10.1037/0003066X.44.3.513

Hobfoll, S.E., Johnson, R.J., Ennis, N., \& Jackson, A.P. (2003). Resource loss, resource gain, and emotional outcomes among inner city women. Journal of Personality gain, and emotional outcomes am
and Social Psycholgy, 84, 632-643.

Holtbrügge, D., \& Mohr, A.T. (2010). Cultural determinants of learning style preferences. Academy of Management Learning \& Education, 9(4), 622-637. http://dx.doi.org/10.5465/AMLE.2010.56659880

Hosford, C.C., \& Siders, W.A. (2010). Felder-Soloman's index of learning styles: Internal consistency, temporal stability, and factor structure. Teaching and Learning in Medicine, 22(4), 298-303. http://dx.doi.org/10.1080/10401334.2010.512832

Joāo, T.F., \& Coetzee, M. (2012). Job retention factors, perceived career mobility and organisational commitment in the South African Financial Sector. Journal of Psychology in Africa, 22(1), 69-76.

Jung, C.G. (1921). The basic writings of C.G. Jung. New York, NY: The Modern Library.

Kiguwa, P., \& Silva, A. (2007). Teaching and learning: Addressing the gap through learning styles. South African Journal of Psychology, 37(2), 354-360. http://dx.doi. org/10.1177/008124630703700211

Kummerow, J.M., \& Quenk, N.L. (1992). Interpretative guide for the MBTI Expanded Analysis Report. Palo Alto, CA: Consulting Psychologists Press.

Lent, R.W. (2013). Career-life preparedness: Revisiting career planning and adjustment in the New Workplace. The Career Development Quarterly, 61(6), 2-14. DOI:10.1002/j 2161-0045 2013.00031.x

Liu, X., Magjuka, R.J., \& Lee, S. (2008). The effects of cognitive thinking styles, trust, conflict management on online students' learning and virtual team performance. British Journal of Educational Technology, 39(5), 829-846. http://dx.doi. org/10.1111/j.1467-8535.2007.00775.x

Moneta, G. B., Spada, M.M., \& Rost, F.M. (2007). Approaches to studying when preparing for a final exams as a function of coping strategies. Personality and Individual Differences, 43, 191-202. http://dx.doi.org/10.1016/j.paid.2006.12.002

Myers, I., McCaulley, M., Quenk, N., \& Hammer, A. (2003). MBTI Manual: A guide to the development and use of the Myers-Briggs Type Indicator. Palo Alto, CA: to the development and use of the
Consulting Psychologists Press.

Naimie, Z., Siraj, S., Abuzaid, R.A., \& Shagholi, R. 2010. Hypothesized learners: Technology preferences based on learning style dimensions. The Turkish Online Journal of Educational Technology, 9(4), 83-92.

Ng, P., Pinto, J., \& Williams, S.K. (2011). The effects of learning styles on course performance: A quantile regression analysis. Academy of Educational Leadership Journal, 15(1), 15-37.

Pajares, F. (1996). Self-efficacy beliefs in academic settings. Review of Educational Research, 66(4), 543-578. http://dx.doi.org/10.3102/00346543066004543

Pool, L., \& Sewell, P. (2007). The key to employability: Developing a practical model of graduate employability. Education and Training , 49(4), 227-289. http://dx.doi. of graduate employability. Education
org/10.1108/00400910710754435

Potgieter, I.L. (2012). The development of a career meta-competency model for sustained employability. Unpublished doctoral thesis, University of South Africa, Pretoria, South Africa.

Potgieter, I.L., Coetzee, M., \& Masenge, A. (2012). Exploring employees' personality attributes in relation to their employability attributes in the business management field. Journal of Psychology in Africa, 22(4), 583-596.

Robinson, I. (2006). Human resource management in organisations. London, England: CIPD.

Rottinghaus, P.J., Buelow, K.L., Matyja, A., \& Schneider, M.R. (2012). The career futures inventory-revised: Measuring dimensions of career adaptability. Journal of Career Assessment, 20(2), 123-139. http://dx.doi.org/10.1177/1069072711420849

Rozendaal, J.S., Minneart, A., \& Boekaerts, M. (2001). The influence of teacher perceived administration of self-regulated learning on students' motivation
and information-processing. Learning \& Instruction, 15, 141-160. http://dx.doi. and information-processing. Learning \&
org/10.1016/j.learninstruc.2005.04.011

Savickas, M.L. (2011). New questions for vocational psychology: Premises, paradigms, and practices. Journal of Career Assessment, 19(3), 251-258. http://dx.doi. org/10.1177/1069072710395532

Savickas, M.L., \& Porfeli, E.J. (2012). Career adapt-abilities scale: Construction, reliability, and measurement equivalence across 13 countries. Journal of Vocational Behavior, 80, 661-673. http://dx.doi.org/10.1016/j.jvb.2012.01.011

Schreuder, A.M.G., \& Coetzee, M. (2011). Careers: An organisational perspective. (4th edn.). Cape Town, South Africa: Juta

Seibert, S.E., Crant, J.M., \& Kraimer, M.L. (1999). Proactive personality and career success. Journal of Applied Psychology, 84(3), 416-427. http://dx.doi. org/10.1037/0021-9010.84.3.416 
Sternberg, R.J. (1997). Thinking styles. New York, NY: Cambridge University Press. http://dx.doi.org/10.1017/CBO9780511584152

Steur, J.M., Jansen, E.P.W.A., \& Hofman, W.H.A. (2012). Graduateness: An empirical examination of the formative function of university education. Higher Education 64(6), 861-874. DOI 10.1007/s10734-012-9533-4 http://dx.doi.org/10.1007/ s10734-012-9533-4

Sugahara, S., \& Boland, G. (2010). The role of cultural factors in the learning style preferences of accounting students: A comparative study between Japan and Australia. Accounting Education: An International Journal, 19(3), 235-255. http:// dx.doi.org/10.1080/09639280903208518

Tshilongamulenzhe, M.C. (2012). An integrated learning programme management and evaluation model for the South African skills development context. Unpublished doctoral thesis, University of South Africa, Pretoria, South Africa.
Tuckey, M.R., \& Hayward, R. (2011). Global and occupation-specific emotional resources as buffers against the emotional demands of fire-fighting. Applied
Psychology: An International Review, 60(1), 1-23. http://dx.doi.org/10.1111/ j.1464-0597.2010.00424.x

Van Dyk, J., \& Coetzee, M. (2012). Retention factors in relation to organisational commitment in a South African medical and information technology services company. South African Journal of Human Resource Management, 10(2), Art. \#433, 11 pages. http://dx.doi.org/10.4102/sajhrm.v10i2.433

Williams, K.F. (2012). Rethinking learning in higher education: viewing the student as social actor. Sheffield, England: Equinox.

Williams, S.B., Rudyk, B.P., \& Staley, D. (2004). Manual and interpretation guide: Exam preparation inventory. Edmonton, Canada: Psychometrics Publishing.

Zhang, L.F. (2004). Revisiting the predictive power of thinking styles for academic performance. The Journal of Psychology, 138, 351-370. http://dx.doi. org/10.3200/JRLP.138.4.351-370 